\title{
Organizational Behavior of Terrorist Groups
}

Jeyong Jung

Korea National Police Agency, Republic of Korea

Dr. Julak Lee (Corresponding author)

Associate Professor, Department of Security Management, Kyonggi University

Republic of Korea

Email: julaklee@kgu.ac.kr

Accepted: May 08, 2015

Doi:10.5296/ jpag.v5i2.7551 URL: http://dx.doi.org/10.5296/ jpag.v5i2.7551

\begin{abstract}
Terror attacks have been typically performed by group members, which implies that perpetrators were not independent actors, but acted violently as being part of a larger group. In addition, the execution of terrorist attacks is not only facilitated by macro-level factors but also as the tools to increase payoffs, survival, and maintenance at the group level. As links between disgruntled individuals and society, organizational behavior elements are something that needs to be examined. In this paper, several organizational behavior theories to compare were applied and contrast between terrorist groups and normal organizations under the categories of mobilizations, decision-making, and leadership.
\end{abstract}

Keywords: Organizational behavior, Terrorism, Terrorism groups, Mobilization, Decisionmaking, Leadership 


\section{Introduction}

The study of terrorism has emerged as one of the most crucial areas of social science research in recent years. Psychopathological approaches on the individual level were rampant among initial research, and are regarded as terrorist activities whose actions are executed by a group who are psychologically sick or pathological. However, not much empirical support has been given for the argument that psychopathological traits of individuals are the predisposition for terrorists as a group compared to non-terrorists (Friedland 1992, Silke 1998, McCauley 2002; LaFree \& Ackerman 2009, McCormick 2003, Ruby 2002, Victoroff 2005). At the group level, organizational approaches were adopted in a way to identify and analyze terrorist organizations in terms of organizational structure and intergroup networks (Arquilla \& Ronfeldt 2001, Asal \& Rethemeyer 2008, Jackson 2006, Krebs 2001, Yang \& Sageman 2009). In particular, Asal \& Rethemeyer(2008) found that the lethality of terrorist groups is predicted by factors of organizational structure such as size, territorial control, and alliance connectedness.

While researchers have focused on individual and macro-level factors of terrorist groups, few studies have addressed the organizational behaviors of terrorist groups. Individual grievance, payoff, and retaliation of terrorists were the main subjects on the individual level, while macro-level factors such as political type (i.e. democracy or autocracy), poverty, economic disparity, or foreign occupation have been studied in order to find the causes of collective grievance. Terror attacks have been typically performed by group members (LaFree \& Ackerman 2009), which implies that perpetrators were not independent actors, but acted violently as being part of a larger group. In addition, the execution of terrorist attacks is not only facilitated by macro-level factors but also as the tools to increase payoffs, survival, and maintenance at the group level. As links between disgruntled individuals and society, organizational behavior elements are something that needs to be examined.

From the organizational behavior perspective, empirical research on terrorism has been proven to be difficult due to clandestinity of the fundamental characteristic of terrorist groups or their illegality (Mayntz 2004). Such clandestinity provides a challenge for researchers to identify terrorist groups. Moreover, the groups' life-span is so short that only a handful of terrorist groups survive and are known to the public. Thus, the lack of long-term observations on terrorist groups due to its short life-span is an impediment for this research. For these reasons, data and samples are, to a large extent, inaccessible or too scarce.

In this review, we examine two research questions that are the nexus between organizational behaviors and terrorism: (1) Do terrorist organizations differ from normal organizations in terms of organizational behavior? (2) Are there some similarities between terrorist groups and normal organizations? To answer these research questions, we explain organizational dynamics of terrorist groups and draw on characteristics of terrorists groups in terms of organizational behavior.

Our review starts from the definition of terrorism which is followed by organization dynamics such as mobilization (i.e. recruitment, motivation, and training), decision-making, and leadership. These subcategories are selected based on our understanding that they are the 
main themes that need to be examined from the aspect of organizational behavior. The last section sums up the characteristics of terrorist organizations by comparing and contrasting them with normal organizations.

\section{Definition of Terrorism}

No single definition of terrorism exists until now, as scholars give different weight to the elements of terrorism, such as the nature of perpetrator, act, target, and intent. The broadest definition we can think of would be the actual or the threat of violence directed against human and nonhuman objects and the narrowest definition would be the actual violence directed against civilians by non-state actors for political purposes.

When it comes to the nature of perpetrators, some scholars (McCormick 2003, Gibbs 1989) do not consider it as an element for broad definitions, while Asal \& Brown(unpublished) limit it to "political actors" and LaFree \& Ackerman (2009) to "nonstate actors". According to a broad perspective of perpetrators, state and social actors such as Animal-liberationist organizations and Stop Huntingdon Animal Cruelty(SHAC) are also defined as perpetrators. Though there is no disagreement that the natures of actions are actual violence, two issues can be brought up here: [1] whether or not violence has to be characterized as illegal (LaFree \& Ackerman 2009, Gibbs 1989) (here, the illegality of violence might be disputable in that there is no agreed international law to define which violence is illegal), and [2] whether the threat of violence needs to be included for a broad meaning of terrorism (McCormick 2003, LaFree \& Ackerman 2009, Gibbs 1989). Researchers who include the threat of violence in their definitions understand threatened violence as a psychological attack and ongoing violence before actual attacks. The majority of scholars define the nature of targets as civilians or non-combatants. This definition distinguishes terrorism from military war or conflict by excluding soldiers as targets (Mayntz 2004). However, Gibbs(1989) broadened this scope to include "human" and "nonhuman objects". The last element we need to examine is the intent. Many scholars (McCormick 2003, Asal \& Brown unpublished, LaFree \& Ackerman 2009) limit it to political purpose, while others (Gibbs 1989, Metraux 1995, Jackson et al. 2005a,b) include religious, environmental, and animal rights issues as other purposes of terrorist groups. For example, PETA, or People for the Ethical Treatment of Animals, is known for inflicting fear and violence against other civilians. These intents distinguish terrorism from organized crime which seeks profits (Mayntz 2004).

Based on these issues, we develop the following definition: Terrorism is the actual or the threat of violence directed against civilians by non-state actors for socio-political goals. Here, "socio-political" refers to political, religious, and other societal meanings. With this definition, we successfully distinguish terrorism from military action and organized crime, while including various forms of terrorism that are not necessarily political.

\section{Terrorist group as an organization}

Barnard (1968) refers to an organization as "a system of consciously coordinated personal activities or forces". An organization has its own members and cooperative system. Terrorist groups have group members and an administrative system of staffing, training, rewarding, 
and decision-making process to achieve collective goals. Also, terrorist organizations have diverse informal organizations within their formal organization, and the cohesiveness generated through relationships among group members acts as one of determinants for achieving goals and their survival. According to Barnard (1968), informal organizations in a formal organization contribute to enhance group cohesion and solidarity so that the connectedness plays an important role in promoting collective activities for the effectiveness and the efficiency of an organization. Likewise, solidarity and connectedness in a group work as motivations for individuals to join terrorist groups (Abrahms 2008; Post et al. 2003).

As a dominant structure of modern organizations, hierarchical organizations that have a "firmly ordered system" share common characteristics in that they have fixed and official principles of the organization such as rules, laws, or administrative regulations and perform the organizational management based on written documents (Weber 1947). Terrorist groups, likewise, have a "top-down" command system in their decision making processes. Many terrorist organizations also have written code of actions and may use it to educate members. For example, the Provisional Irish Republican Army (PIRA) published a manual or "the Green Book" which listed "the duties and responsibilities of volunteers as well as explaining the history of movement, the rules of military engagement, and anti-interrogation techniques" (Collins \& McGovern 1998; Jackson et al. 2005b).

\section{Mobilization}

This section consists of three sub-themes: recruitment, motivation, and training.

\subsection{Recruitment}

There are two types of recruitment. While terrorist groups actively seek recruits, individuals themselves try to voluntarily join the groups. The first type is top-down recruitment and the second type is bottom-up recruitment (Hegghammer 2006). Hegghammer(2006) examines how terrorists in Saudi Arabia were recruited to Afghanistan. He refers to "top-down" as an enlistment of potential terrorists by an appointed recruiter and "bottom-up" as joining terrorist groups by recruits themselves based on self-radicalization.

In terms of top-down recruitment, normal organizations send their personnel employees to places where future recruits are concentrated to scout high-quality individuals for growth of their organizations (e.g. schools). But terrorist groups cannot delegate their members to open institutions to hire highly skilled individuals due to their clandestinity; instead, they recruit from other terrorist groups. For example, Al-Qaida recruited the majority of their operational members from jihadist groups such as EIJ and from the mujahidin of Islamic resistances in Kashmir, Bosnia, Chechnya (Gunaratna 2002; Borum \& Gelles 2005). The other way is using social institutions. Aum Shirikyo whose ideology was to create a religious nation through "holy war" attracted core members through sermons in their institutions (Metraux 1995). Recruitment of Al-Qaida was conducted in informal religious study groups, social gatherings, or schools (Hegghammer 2006).

The bottom-up type is the more frequent form of recruitment among terrorist groups. One route of voluntary recruitment is by following their friends or members of their family (Post 
et al. 2003). Such recruitment through close contacts is facilitated when there is a consensual community support from terrorist groups. The other route is when individuals volunteer without any connection to members inside terrorist groups. These voluntary enlistments are generally instigated when individuals are attracted by a group's ideology and goals, material incentives, social status and solidarity.

We can classify the reasons why individuals are recruited into purposive and non-purposive ends or political and nonpolitical incentives (Creanshaw 1985). Some members join a group to achieve a political or religious purpose, while others are attracted by incentives such as "comradeship, social status, excitement, and material reward" (Crenshaw 1985). If collective grievances are deeply rooted in community, community members tend to strongly espouse ideology or goals of terrorist groups. A favorable atmosphere in the community makes individuals be more attached to ideology and goals of terrorist groups. With regard to non-purposive ends, after interviewing 21 Islamic terrorists and 14 secular terrorists, Post \& Sprinzak \& Denny (2003) found that many youngsters joined terrorist groups for financial assistance for their families and for personal honor. The material reward is a typical incentive for job-seekers, where a guarantee of high salary or benefits creates a high likelihood for job-seekers to apply for those organizations. Also, acquiring a highly reputable position, such as getting a public sector job that provide personal or family honor is another incentive for individuals to take the job.

If we posit that recruitment processes are determined by the equilibrium between labor demand and supply, labor demand on the aspect of terrorist organizations should be carefully examined. Mesquita(2005) argues that the quality of actual terrorist is higher than the quality of people willing to become terrorists because of the screening by terrorist groups. His argument is empirically supported by the accounts of leaders of Hamas and al-Qassam who claim that there were enough terrorist hopefuls so that the hopefuls are screened by selection process (Hassan 2001). To increase the quality of the group, Aum Shinrikyo primarily hired professors, politicians, high ranking officials in government agencies (Kaplan \& Marshall 1996). Also, most of the $9 / 11$ hijackers were highly educated and from "comfortable middle-class families in Saudi Arabia and Egypt" (Post et al. 2003).

\subsection{Motivation}

Motivating group members by various incentives is crucial for two reasons: (1)the achievement of stated goals and (2) the organizational survival and maintenance. According to Maslow(1943)'s human motivation theory, there are five basic needs for human beings: the physiological needs, the safety needs, the love needs, the esteem needs, and the need for self-actualization that have hierarchical structure of predominance. Therefore, many organizations provided their members not only with monetary rewards by which workers basically maintain their lives but also with an opportunity to have a sense of their presence in a community or society by giving them a position and a reputation. Likewise, terrorist organizations also try to fill the five basic needs of members by furnishing monetary rewards and offering the opportunity for action and self-actualization.

Terrorist groups provide group members with material incentives in order to encourage 
obedience to the organization and to facilitate the productivity of group members (Crenshaw 1985, Kellen 1979). Crenshaw(1985) argued that material incentives possess limited effects on motivating members if the underground life cannot provide their members with enough money or income compared to other normal jobs. But Kellen(1979) pointed out that terrorists are motivated by affluence so that terrorists no longer need to work for daily jobs.

Through the comparison between instrumental model (strategic model) and organizational model, Crenshaw(1987) touches on the incentives for group members within internal processes of organizations for their survival. He suggests two incentives: (1) ideological incentive and (2) the sense of solidarity. In the first incentive, "ideological goals" promise members a bright future. On the same theme, LaFree \& Ackerman (2009) suggest that ideology not only reflects collective grievances but also functions as motivations by implying how to resolve grievances.

The second incentive is another type of intangible incentive, where "social status and reputation", "comradeship", and "admiration of peers and family" are predicated on "a feeling of belonging", "cohesion", and "solidarity". The sense of solidarity is what Abrahms(2008) argues as the most important incentive in terrorist groups. Based on Barnard(1968)'s organizational theory, or the nature systems model, he argues that terrorists partake in groups for the achievement of social solidarity not for stated ideological agendas, pointing out weaknesses of the strategic model. According to Schein (1970)'s group dynamics theory, people have various social needs and can fulfill these needs by grouping and forming an organization. By being a member of an organization, an individual affiliates him or herself to a group and feels a sense of belonging by sharing common goals and performing certain group activities in order to achieve goals. Also, through group membership, a person can learn who he or she is and obtain social status in the group. In this way, an organization helps their members to maintain self-esteem. Through acquiring recognition from a group as a social being, group members feel self-fulfillment. However, Post et al.(2003) offers a different view. Though they accept the idea that group membership provides members with social status and power, they argue that once individuals become members of the groups, individual goals are assimilated into group goals and, ultimately, group collectiveness takes precedence over the individual.

\subsection{Training}

Organizational knowledge is more than just the sum of individual knowledge (Jackson et al. 2005a). To develop organizational knowledge that determines survivability of organizations is a critical matter. In the case of Al-Qaida, the dominating form of training was to take advantage of physical training camps, but training in a "home school environment, on the job, or over the internet" has been deemed another form of sustaining organizational learning (Borum \& Gelles 2005).

Modern organizations train recruits and existing members for technical skills to increase effectiveness, efficiency, and adaptability. Terrorist groups clandestinely train their members for particular skills such as assassination and explosion in training camps that are located in remote areas. For example, Al-Qaida's training camps, which used previous "facilities and 
equipment from the Afghan war against the Soviets," are one of the most well-known training camps and tens of thousands of trainees experienced their training in Al-Qaida camps in Afghanistan and Sudan (Gunaratna 2002; Borum \& Gelles 2005).

However, small organizations rarely have capabilities to develop internal training systems, which enable them to train their members (Jackson et al. 2005b). Therefore, terrorist groups depend on training camps or programs of other terrorist groups. By sharing training camps and programs, terrorist groups acquire and distribute information and knowledge among themselves. This argument is supported by Jackson et al. (2005b) who collected and analyzed data from five terrorist groups: Hizbollah, Jemaah Islamiyah, Provisional Irish Republican Army(PIRA), Aum Shinrikyo, and the radical environmentalist movement. Hizbollah was provided with training of using new weapons by Iran's Revolutionary Guards and sent their fighters to be trained in Palestinian camps. As a reciprocal give-and-take, Hizbollah created its own base and offered its training to Islamic Jihad and the Popular Front for the Liberation of Palestine-General Council. Jemaah Islamiyah gained access to Al-Qaida training camps in Afghanistan, MILF camps in the southern Philippines, and Jihadist camps in Indonesia and Malaysia, learning how to use firearms and military tactics. Animal-liberationist organizations participated in a training camp of Stop Huntingdon Animal Cruelty(SHAC) in September 2004. In the case of Provisional Irish Republican Army, however, it trained its members through its own training unit. It did not have to rely on other groups' camps and programs, but it multiplied its knowledge by exchanging ideas and skills with other groups such as Basque Fatherland and Liberty(ETA) and the Palestine Liberation Organization(PLO).

Aum Shinrikyo's training style was different from other terrorist groups in that it took advantage of foreign legal training programs such as pilot training program in Florida and training for Russian Spetznaz forces (Jackson et al. 2005b). Its access to training programs offered by legal entities is attributed to the fact that Aum Shinrikyo was not designated as terrorist groups at the time. From the comparison between the first four groups and Aum Shinrikyo, we can find that once certain groups are designated as terrorist groups by states, secrecy and clandestinity become a group's top priorities. Consequently, those groups tend to limit the scope of acquisition and distribution of knowledge and skills to terrorist group networks. This limitation hampers designated terrorist groups from tapping into weapons and skills of legal organization or states.

However, training of terrorist groups not only increased knowledge and skills but also facilitated indoctrination of their political or religious ideology and creeds. The content of trainings are not restricted to technical expertise and tactics, but also includes indoctrination processes. For example, Jemaah Islamiyah offered religious classes and PIRA published "the Green Book" that included the history of the movement. Also, al-Qaeda on the Arabian Peninsula trained recruits in training camps by four main processes: violence acculturation, indoctrination, training on tactical and operational attack skills, and relationship-building with other members (Hegghammer 2006). Trainees are implicitly or explicitly imbued with ideological point of views. The indoctrination process is imperative for leaders of terrorist groups to maintain their groups. In many groups, the need to maintain their groups replaces 
other goals such as successful attacks or withdrawal of foreign forces. In order for these group to prolong their survivability, maximizing group cohesion, solidarity, and loyalty to leadership through indoctrination process becomes another important objective of training.

There are two reasons why indoctrination processes are critical in terms of maintaining their groups. The first reason is related to the organizational structure. Crenshaw(1985) suggested the "cellular structure" which consists of a top unit and compartmentalized subordinate units. In the cellular structure, operational units at the same level are not well connected and isolated from each other (Mayntz 2004). Also, communication between a top unit and operational units are limited, for the identities of leaders should not be disclosed by opponents. On these structural aspects, relationships between units, whether they are hierarchical or horizontal, is easy to be weakened over time. To overcome these weaknesses, solidifying and strengthening cohesiveness through indoctrination processes is needed. The second reason comes from the argument that organizational goals are ambiguous and inconsistent (Crenshaw 1985, Crenshaw 1987). The fact that terrorist groups change their goals for organizational survival may confuse their members. These confusions might lower loyalty to a leadership or organization itself and may increase attrition rates. If terrorist groups succeed to indoctrinate their members, those groups are less likely to experience loyalty and attrition problems.

\section{Decision-making}

How do terrorist groups make decisions for the commitment of violence? Decision making is the cognitive process by which individuals compare possible options and finally a course of action is taken. Terrorism like any other activity is the product of an incessant decision making process by terrorists or terrorists organizations. All the strategies and tactics are chosen through a process, even though such processes might not be noticeable to outsiders or even to insiders who are not directly in the process. While individual terrorism involves the decision making process that can be explained by individual psychology (McCormick 2003), group decision making is the collective process through group psychology.

\subsection{DecisionOmaking Structure}

Who participates in the decision making? Are decisions made by only leaders or is decision-making more participatory? The structure of decision making is directly related to organizational structure, which is based on the theory that organizations are viewed as decision-making entities (Boudreau 2004). For this reason, organizational structures such as hierarchy and horizontal are determined by decision making processes.

\subsubsection{Hierarchical decision-making (top-down)}

On the overall group level, hierarchy, which is the main characteristic of bureaucracy, prevails terrorist organizations. The hierarchy of those groups is created by a small number of decision-makers. Jackson (2009) assumes that decisions in terrorist groups are made by members within "decision-making units" in terrorist groups, excluding members out of the units. The definition of "decision-making units" is made by two concepts: authority and influence. It means that members with authority and influence over others are considered to 
be within the "decision making units". In the case of Hezbollah, the decision-making unit was a small and select group of Lebanese clerics (Ranstorp 1994). Similarly, Post et al. (2003) found that decision-making in Middle Eastern terrorists groups takes the similar form between religious groups and secular groups. Decision-making was accomplished by commanders at the top. Middle Eastern terrorists outside the units were allowed to ask operational details, but not allowed to question "whether or not the authorized act should be carried out". What Jackson (2009) studied are the factors that shaped decision-making by terrorist groups. Here, he argues that six factors: external audiences, goals and interests, internal group dynamics, the view of the risks, committed resources, and enough information contribute to influence the decisions that they make.

\subsubsection{Hierarchical decision-making (bottom-up)}

Though high-ranking members distribute their goals, strategies, and very general directives, operational tactics and specific directions are made in operational units. Members in operational units have a large degree of autonomy when it comes to operational decision making (Crenshaw 1985). The tactical decisions are discussed and made on the level of those units rather than hierarchical leadership. This is a significant phase of decentralization. Crenshaw(1985) attributes the decentralization and autonomy to "organizational constraints imposed by clandestinity and secrecy". Leaders have a restricted role in giving out down-to-earth directives because of the fear of being identified and caught. Another explanation might be the situational context of their operations. Their operations are performed in exigencies that require immediate actions. To conduct effective terror attacks, they need to be nimble and flexible depending on a situation. Operators can immediately change their tactics when unexpected factors that might affect the success of their attack are encountered.

\subsection{Mechanism}

\subsubsection{Rational choice approach}

Decision-making in terrorist groups can be evaluated by two distinct theoretical frameworks: rational choice approach and group psychology approach. The rational choice approach in terrorism is predicated on the assumption that the terrorist groups choose amongst alternatives that produces the best outcomes compared to the cost of their resources. This approach is empirically supported by several cases on the bargaining table to determine the costs and benefits for both parties, such as the Northern Ireland case (Brams \& Togman 1998). In addition, suicide attacks are understood as "instrumental tactics" and "strategic logic" in order to obtain organizational objectives by minimizing costs and maximizing benefits (Hoffman \& McCormick 2004, Pape 2003). This approach explains that terrorist groups end the use of terrorism when costs are too high and that non-violent terrorist groups start to use violence when cost and benefit structure changes due to contextual changes.

\subsubsection{Group dynamics}

There is a shared belief that terrorists as a group are counterparts to government soldiers, perceiving themselves as actual soldiers who need to achieve political objectives. This belief 
leads them to wage a "fantasy war"(Ferracuti 1990; McCormick 2003). This illusion makes terrorists impatient for results, thus predisposing themselves toward action rather than words. It is "a bias toward action" (McCormick 2003), notion that is supported by interviews with Islamic and secular terrorists (Post \& Sprinzak \& Denny 2003). McCormick (2003) argues another feature of group dynamics which is the adoption of historical precedents. When terrorist groups are in the process of decision making, they adopt the past experiences of their predecessors. It is a way of passing on tactics and procedures as "a historical legacy" to successors (Johnson 1973, McCormick 1993; McCormick 2003). This represents a tendency to follow a group's tradition rather than following strategic calculation.

In group dynamics, it is not easy for terrorists groups to change their group tendencies, such as propensity for actual violence and preference for historical inheritance. They fall into the vulnerability to groupthink (McCormick 2003). Groupthink in a closed and clandestine organization tends to be more exposed to the vulnerabilities, such as "taking extreme risks", an "unquestioned belief in the group's inherent morality" and, more critically, the lack of reasonable restraints on blind beliefs of groups (McCormick 2003). The prohibition on questioning over top-down orders represents an "absence of critical thinking" in groups (Post \& Sprinzak \& Denny 2003).

\section{Leadership}

Analyzing leadership of terrorist groups is extremely difficult, for information on leaders such as family/educational backgrounds, personality and previous careers are not open to the public. The disclosure of the groups' leadership might directly lead to the assassination or capture of their core leaders. This inherent limitation may be a factor in the scarcity of previous research on the leadership of terrorist groups.

Previous studies on the leadership of terrorist groups have focused on its patterns or underlying origins. Crenshaw (1985) argues that leaders depend upon "two rational sources of authority," which are firstly "skills" accumulated from their previous experiences and secondly their "position" as an "agent of impersonal force". Skills of leaders make followers perceive that their leaders have a large amount of expertise and information, which refers to expertise and information powers (Hersey \& Blanchard \& Natemeyer 1979). Also, the high ranking position of leaders within a group indicates that leaders possess inherent authority and power, otherwise referred to as legitimate power. The leadership derived from such positions is a typical feature of normal organizations that Weber argued. Weber(1947) suggested three types of legitimate authority: rational grounds based on "legality" of patterns of normal rules, traditional grounds based on conscious or unconscious belief on historically sanctioned position of a person, and charismatic grounds based on personal loyalty. Traditional grounds or legitimate authority are what leaders get when they are positioned at the top. This style of leadership can be seen in Hizbollah. Ranstorp (1994) found that Hezbollah's command leadership, a type of leadership portrayed as a "supreme political religious leadership, was composed of a small number of Lebanese clerics and was closely associated with Iran's leadership and, to a lesser degree, Syria's leadership. Hezbollah's leadership style was an authoritative one that ensures follower's loyalty and blind obedience. 
Such leadership takes the symbolic form rather than actual reflection of leadership and members revere and worship their leaders.

Even though legitimate authority and its origins are typical in most of organizations, it does not guarantee success or survivability of organizations. Legitimate leadership is formally noticeable to group members and even to outsiders, but the formality does not necessarily lead to substantial influence on subordinates. For this reason, it is true that organizations have tried to search other types of authorities. Bernard (1968) argued that communications between a leader and subordinates are crucial to enhance substantial influence of a leader on subordinates. By communication, a leader gets to identify needs of subordinates, thus make changes to reflect their needs. Previously, modern organizations have depended on authoritative power, but they are changing into cooperative leadership based on two way communications. In the cooperative leadership, empowerment and delegation occur in a way to reflect needs of group members.

The transition of leadership in normal organizations can be found in terrorist organizations. In the study of Al-Qaida, Borum \& Gelles (2005) explained the dynamics of Al-Qaida's leadership and analyzed the transition of the leadership from the first generation to the second one. As the seasoned leaders have been killed and captured, Al-Qaida has transformed its leadership to be decentralized by recruiting young leaders with skilled experiences. The role of the core leadership around Usama Bin Laden changed from directing tactics on the field to inspiring terrorists on the field, which is called "inspirational leadership". The inspirational leadership provides its members with symbolic meanings to justify and encourage their terrorism. On the other hand, field commanders and operators have more leeway to exercise their discretions while in operation.

The commonality between Hizbollah and Al-Qaida is that their leaderships were predicated on legitimate power and charismatic leadership. As Crenshaw(1985) argued, legitimate power comes from a position that is the highest rank in a terrorist organization. Once individuals are positioned on top seats, they have legitimate power to order through chain of command. Another explanation can be found in religion. They borrowed legitimacy from their Islamic doctrines. By depicting leaders as heroes or worshipped leaders, terrorist groups solidified and strengthened legitimate power. Also, their religion or Islam was a source of charismatic leadership. Religious legitimacy imbued the core leaders of both groups with charismatic leadership that made supporters and followers be obedient to their religious leaders. Similarly, the leader of Aum Shinrikyo, Shoko Asahara, built up charismatic leadership by coaxing followers to believe that he had supernatural powers (Kaplan \& Marshall 1996, Metraux 1995).

\section{Characteristics of Terrorist Organizations}

Based on the examination above, we point out some characteristics of terrorist groups.

\subsection{Clandestinity}

Terrorist groups as violent underground organizations need to keep their members, strategies, and future plans a secret. Secrecy or clandestinity is the dominating characteristic that deeply 
permeates the whole organization. Basically, the scope of every move of terrorist groups is conditioned by the need for secrecy. It explains why terrorist groups are separated from the larger social and political environments (Crenshaw 1985). Not only that, this characteristic distinguishes terrorist groups from nonviolent political groups (McCormick 2003). In recruitment, terrorist groups could not tap into open job markets to attract talented individuals, but recruited individuals from other terrorist groups or carefully used social or religious institutions. Al-Qaida and Aum Shinrikyo were good examples. In terms of training, terrorist groups are interconnected to share and multiply information and skills among themselves (Jackson 2006). The creation of training networks contributes to the formation of underground worlds as a living system as opposed to "open" surroundings. Also, small terrorist groups that do not have capabilities to train their members depend on training camps or programs of other terrorist groups. Lastly, concerning decision-making, McCormick (2003) argues that the need for secrecy calls for decision making processes to be closed and clandestine, while Crenshaw(1985) attributes decentralization and autonomy to "organizational constraints imposed by clandestinity and secrecy". Therefore, terrorists in operational units have a large degree of autonomy when it comes to operational decision making (Crenshaw 1985).

\subsection{Risk-lover}

The large number of people who join normal and legal organizations have risk-aversive or risk-neutral tendencies, but terrorists tend to be risk-lovers. Many terrorists are motivated to conduct extreme violence by virtue of political ideologies and religious creeds. According to Maslow(1943)'s human motivation theory, when group members satisfy lower needs such as safety needs first, higher needs such as self-actualization emerge. However, even though terrorist know that their involvement in terror attacks makes them feel a huge threat to their safety, they want to actualize themselves by sacrificing themselves. This phenomenon cannot be explained by Maslow(1943)'s theory and shows a unique feature of terrorists compared to employees in normal organizations. For this reason, scholars considered terrorist groups and have tried to explain the psychological mechanism of this rare phenomenon in the normal organizations.

\subsection{Goal ambiguity}

Objectives of terrorist groups are not necessarily accurate and consistent (Crenshaw 1985, Crenshaw 1987). For example, Al-Qaida fights for "establishing a government which follows the rule of the Caliphs" and Animal-liberationist Front strives to reduce animal suffering in the world. The ambiguity of goals results in frequent changes of operational goals and strategies, conveying an alternative understanding of the organizational goals by group members. Such goal ambiguities transmit confusing messages to group members and thus may lower their loyalty to leadership and increase attrition rates. To lessen problems from goal ambiguity, terrorist groups emphasize indoctrination processes during training.

\subsection{High exit costs}

Previous costs that individuals paid greatly affect their future decisions. When humans make 
decisions, they are bounded by previous costs rather than future costs, thus acting irrationally. This is what scholars in behavior economics call, sunken cost. Similarly, terrorist groups force recruits to pay high costs by involving new members in actual terrorist attacks. Terrorist attacks translate into high costs in that the attacks not only seriously damage civilians but also put the perpetrators in opposition to civilians and governments. In this sense, the involvement in terror attacks after recruitment implies high sunken cost. Once terrorists paid a lot by committing the attacks, it will affect the decision on defection from groups (Crenshaw 1985). The continuous involvement in terror attacks separates perpetrators from government counterparts and social and political surroundings, thus isolating them from the outside. This situational context strengthens the effect of sunken cost. As the sunken cost increases with more terror attacks, terrorists are more likely to remain in groups. Therefore, high sunken cost leads to high exit costs.

\subsection{Dual decision-making process}

Overall decision-making processes of terrorist groups takes the form of hierarchical structure, but decentralization and empowerment to operational units make field commanders and operators have a large amount of discretion on the scene. This dual structure of decision-making is quite similar to some organizations, which have to deal with emergency situations. For example, Police, military, and paramedics as first responders to emergencies take the similar decision-making structure that possesses both hierarchical and horizontal styles. Headquarters disseminate their organizational objectives, strategies, and general directives, while officials in operational units have a large extent of discretion when they are on the field. For these first responding agencies, the "situational context" explanation suggested on the above section can be applied. The fact that operational units are situated in exigencies means that operators need to rely upon their own decisions after interpreting the situation. In this sense, the situational context strengthens the horizontal structure of field units. However, clandestinity of terrorist groups contributes to the dual decision-making process that allows co-existence of the chain of command and empowerment to field operators, while the first responding agencies as legal entities have open communications between leaders and field members without worrying about information disclosures.

\section{Conclusion}

Social research on terrorism has been progressing steadily, but still there are many areas that have not been covered. One of them is a study on terrorist organizations in terms of organizational behavior. What we examined in this review is that how group dynamics differ from individual aspects and how behaviors of terrorist organizations are different from or similar to normal organizations. These questions are important because answers from them might explain behaviors of terrorist groups that cannot be explained by other aspects. We applied several organizational behavior theories to compare and contrast between terrorist groups and normal organizations under the categories of mobilizations, decision-making, and leadership. More future research on this topic will generate a deep understanding of organizational behaviors of terrorist groups. 


\section{Macrothink}

Journal of Public Administration and Governance

ISSN 2161-7104

2015, Vol. 5, No. 2

\section{References}

Abrahms, M. (2010). What Terrorists Really Want: Terrorist Motives and Counterterrorism Strategy. International Security, 32(4), 78-105.

Arquilla, J., \& Ronfeldt, D. F. (2001). Networks and netwars: the future of terror, crime, and militancy. Rand Corporation.

Asal, V., \& Brown, M. (unpublished). Why use terrorism? An organizational examination of the choice to target civilians.

Asal, V., \& Rethemeyer, R. K. (2008). The Nature of the Beast: Organizational Structures and the Lethality of Terrorist Attacks. Journal of Politics, 70(2), 437-449.

Barnard, C. I. (1968). The Functions of the Executive (30th ed.). Harvard University Press.

Borum, R., \& Gelles, M. (2005). Al-Qaeda's operational evolution: behavioral and organizational perspectives. Behavioral Sciences \& the Law, 23(4), 467-483.

Boudreau, J. W. (2004). Organizational Behavior, Strategy, Performance, and Design in Management Science. MANAGEMENT SCIENCE, 50(11), 1463-1476.

Brams, S. J., \& Togman, J. M. (1998). Cooperation through Threats: The Northern Ireland Case. PS: Political Science and Politics, 31(1), 32-39.

Crenshaw, M. (1985). An organizational political approach to the analysis of political terrorism. Orbis, 29(3), 465-489.

Crenshaw, M. (1987). Theories of terrorism: Instrumental and organizational approaches. Journal of Strategic Studies, 10(4), 13.

Gibbs, J. P. (1989). Conceptualization of Terrorism. American Sociological Review, 54(3), 329-340.

Hassan, N. (2001). An Arsenal of Believers. New Yorker, 77(36), 36.

Hegghammer, T. (2006). Terrorist Recruitment and Radicalization in Saudi Arabia. Middle East Policy, 13(4), 39-60.

Hersey, P., Blanchard, K. H., \& Natemeyer, W. E. (1979). Situational Leadership, Perception, and the Impact of Power. Group \& Organization Management, 4(4), 418 -428.

Heymann, P. B. (2001). Dealing with Terrorism: An Overview. International Security, 26(3), 24-38.

Hoffman, B., \& McCormick, G. H. (2004). Terrorism, Signaling, and Suicide Attack. Studies in Conflict and Terrorism, 27(4), 243-81.

Jackson, B., Baker, J., Chalk, P., Cragin, K., Parachini, J., \& Trujillo, H. (2005a). Organizational learning in terrorist groups and its implications for combating terrorism. RAND corporation, 1-214. 
Jackson, B., Baker, J., Chalk, P., Cragin, K., Parachini, J., \& Trujillo, H. (2005b). Case studies of organizational learning in five terrorist groups. RAND corporation, 1-214.

Jackson, B. A. (2006). Groups, Networks, or Movements: A Command-and-Control-Driven Approach to Classifying Terrorist Organizations and Its Application to Al Qaeda. Studies in Conflict \& Terrorism, 29(3), 241.

Jackson, B. A. (2009). Organizational Decisionmaking by Terrorist Groups(chapter six). In Social science for counterterrorism: putting the pieces together, ed. Paul K.Davis, Kim Cragin. Rand Corporation.

Kaplan, D. E., Marshall, A. (1996). The Cult at the End of the World. Crown.

Kellen, K. (1979). Terrorists — What are They Like? RAND corporation, 78.

Krebs, V. (2001). Mapping Networks of Terrorist Cells. Connections, 24(3), 43-52.

LaFree, G., \& Ackerman, G. (2009). The Empirical Study of Terrorism: Social and Legal Research. The Annual Review of Law and Social Science, 5, 347-374.

Maslow, A. H. (1943). a theory of human motivation. Psychological Review, 50, 370-396.

Mayntz, R. (2004). Organizational Forms of Terrorism : Hierarchy, Network, or a Type sui generis? MPIfG Discussion Paper.

McCormick, G. H. (2003). Terrorist Decision Making. Annual Review of Political Science, 6(1), 473-507.

Mesquita, E. B. D. (2005). The Quality of Terror. American Journal of Political Science, 49(3), 515-530.

Metraux, D. A. (1995). Religious Terrorism in Japan: The Fatal Appeal of Aum Shinrikyo. Asian Survey, 35(12), 1140-1154.

Pape, R. A. (2003). The Strategic Logic of Suicide Terrorism. American Political Science Review, 97(3), 343-361.

Post, J., Sprinzak, E., \& Denny, L. (2003). The Terrorist in their own words: Interviews with 35 incarcerated Middle Eastern Terrorists. Terrorism and Political Violence, 15(1), 171-184.

Ranstorp, M. (1994). Hizbollah's command leadership: Its structure, decision-making and relationship with Iranian clergy and institution. Terrorism and Political Violence, 6(3), 303.

Ruby, C. L. (2002). Are Terrorists Mentally Deranged? Analyses of Social Issues \& Public Policy, 2(1), 15-26.

Schein, E. H. (1970). Organizational Psychology (2nd ed.). Prentice Hall.

Victoroff, J. (2005). The Mind of the Terrorist. Journal of Conflict Resolution, 49(1), 3-42.

Weber, M. (1947). The Theory of Social And Economic Organization. Free Press.

Yang, C. C., \& Sageman, M. (2009). Analysis of terrorist social networks with fractal views. 
Journal of Information Science, 35(3), 299-320. 